УДК 339.138:004.738.5

JEL Classification: F20, F23

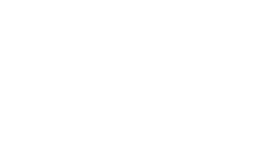

Head of the Department of innovat

Petro Pererva

Doctor of Economics, Professor ave entrepreneurship management and international economic relations

Valerii Kobieliev

Ph.D. in Economics, Associate Professor Deputy Director of the Educational and Scientific Institute of Economics, Management and International Business

Iryna Dolyna

Ph.D. in Economics Associate Professor of the Department of innovative entrepreneurship management and international economic relations National Technical University «Kharkiv Polytechnic Institute»

(Kharkiv, Ukraine)

\title{
DIGITAL MARKETING: OPPORTUNITIES AND PARADOXES OF COMMUNICATIONS
}

The emergence of digital networks in human society, in marketing activities is a vital need of society to share information. Opportunities for digital marketing, digital technologies allow companies not only to meet the needs of their customers, but also to attract them to their business, while the customer receives income. The article highlights the main trends in the work of enterprises in the formation of customer experience: the consumer becomes an accomplice, co-creator of the business process; creation of cloud services opens new opportunities; the system of marketing communications allows to personalize offers to clients taking into account their interests and previous purchases. It is proved that digital transformations in marketing are characterized by some paradoxical manifestations. Among them: a large consumer base is not the basis for the right strategy; digital marketing does not reduce the time to buy; advertising not only promotes the product, but also harms it and tends to decorate the subject of advertising; anti-advertising can become advertising, etc.

Keywords: digital transformations, marketing, advertising, paradox, trend, consumers, strategy, industrial enterprises

\section{DOI: 10.15276/mdt.4.4.2020.1}

Statement of the problem in general form and it's connection with important scientific or practical tasks. The main task of managers lies in careful market research, identifying the benefits of potential and actual customers. Given the dynamism of the environment and the influence of various factors, the actions of customers are often undesirable for the company, resulting in the need for their management.

The latest modern method of managing customer behavior are digital marketing technologies, in the narrow sense are a set of effective tools, and in a broad sense - a concept aimed at attracting and retaining the customer.

(C) 2020 The Authors. This is an open access article under the CC BY license (http://creativecommons.org/licenses/by/4.0) 
This method of comprehensive promotion of goods, services, ideas or brand is designed to ensure the visibility of the company in the market, increase the loyalty of regular customers, promote new offers on the market and expand the customer base.The uniqueness of digital marketing technologies is based on a high degree of personalization of customers, the product is introduced at the right time in a specific segment of the target audience in accordance with the identified interest in it. But the main advantage of using digital technology is the close twoway communication with the customer by collecting opinions and feedback from stakeholders immediately after the launch of the advertising campaign. The key aspects of the study of digital marketing are tools with their areas of application.

The World Wide Web, digital television, mobile devices, smart gadgets and interactive screens are the channels through which goods are brought to market. Digital marketing technologies are a set of tools to influence customer behavior online and offline. Without access to the Internet resource, the buyer can take an active part and keep in touch with the company through media and viral advertising, SMS-mailings, teasers and banners.

This concept is often confused with Internet marketing. However, digital marketing has a significant difference. Digital marketing includes internet marketing too, but the internet is not limited. Let's compare: internet marketing is SEO-site promotion, context, webinars, etc. meaning all channels that are available to the user only on the Internet. And digital marketing is all of the above plus advertising and promotion on any digital media offline. That is, it refers to digital communication that takes place both online and offline. In addition, digital marketing does not include promotion through such traditional channels as newspaper ads, flyers, television advertising, big boards. If the billboard has a QR-code with which you can go to the site, then this is digital marketing.

Accordingly, the concept of "digital marketing" is not identical to the concept of "Internet marketing", and a significant difference is that digital marketing uses not only the global Internet, but also digital, including offline channels to promote the product, and also attracting and retaining customers

The analysis shows that the development of information technology (digitization) is not enough for digital transformation, business processes need to be restructured, new business models and strategies are formed, people are trained and adapted, digital culture and digital society are formed. It is important that these processes are interconnected, and the potential of the organization must be considered in the context of the ecosystem. In this regard, conducting research in the field of digital marketing is an important and urgent task.

Analysis of the latest research and publications, which initiated the solution of this problem and on which the author relies. The problems of digital marketing have been reflected in numerous studies and publications. The development of the theory and practice of digital marketing has been engaged in such foreign researchers as R. Ackerman, I. Ashmanov, B. Berman, F. Virin, J. Weibe, O. Kent Wertheim, F. Kotler, I. Mann, J. Lacom, I. Fenwick, H.Hershgen and others. Among domestic scientists: S. Gritsenko, S. Ilyashenko, M. Oklander, T. Oklander, O. Kosenko, N. Tkachova, V. Ruban, Y. Shipulina, D. Yatsyuk. Despite the significant number of scientific and practical achievements in the theory and practice of digital marketing, at present there are no uniform research methods in this area. The diversity of researchers' views is due to the many tools of digital marketing and the identification of digital and Internet marketing. This increases the need for in-depth study of the features of the use of digital marketing in the enterprise.

Highlighting the previously unresolved parts of the general problem to which the article is devoted. At the same time, the issues of scientific substantiation of the role and place of digital marketing in modern conditions of enterprise development, strengthening its role in 
promoting products on a competitive market, explanation of some paradoxical provisions in the theory and practice of digital marketing remain controversial.

Formulation of the purpose of the article (statement of the problem). The aim of the article is to study the features of digital marketing as a modern tool for managing consumer communications, substantiation of theoretical and practical provisions for the use of digital marketing in promoting products to the target market, as well as identifying and explaining certain paradoxes of digital marketing.

Statement of the main material of the research with full justification of the scientific results obtained. The changes we see as a result of the development of the digital economy sometimes cause some surprise and misunderstanding. Even the speed and mechanics of digital transformation are significantly different from what was in previous economic cycles of development. The concentration of knowledge and technology, their various combinations and system integration, the dynamics of processes radically transform individual market segments and entire industries.

Changes are taking place even in areas that were previously considered conservatively stable or even archaic. The usual course of business processes is repeatedly disrupted in a particular area of economic activity or public administration. Paradoxically, a new "digital" business is invading an industry that has shaped its markets, business models of its production and commercial activities, communication channels, and market infrastructure for decades. $\mathrm{He}$ begins to make her unrecognizable. Most of the old players at the same time, inertial procrastinating in the first stage or simply losing sight of a new aggressive competitor, quickly begin to lose their market position. Particularly convincing is the speed, complexity and scope of such processes. Sometimes the changes are so strong and rapid that they require state intervention.

There is a lot of talk today about the digital economy. At the same time, we would like to note that in the conditions of digital transformation human communication will not lose its significance. Because, first of all, you need connections with people. In the information space, trust, agreement and loyalty in relations at the macro and micro levels become especially important and are the basis for long-term interaction of economic entities.

The emergence of digital networks in human society, in marketing activities is a vital need of society to share information. Since ancient times, mankind has sought to find the means to transmit messages quickly and reliably. Therefore, the emergence of digital networks is not so much a scientific achievement as a historical pattern.

At the same time, the development of information technologies to some extent leads to the emergence of information crises, the emergence of significant problems in the information space, reducing the efficiency of information exchange in society. This conclusion can be explained by the following factors:

- the volume of information published is sharply increasing;

- there are difficulties in communication between groups of different professionals;

- the volume of unpublished information increases;

- the urgency of the problem of marketing communications, the needs of interlingual exchange in the world is constantly increasing.

In our opinion, it is necessary to highlight a certain paradox of social communication in an information crisis. The essence of this paradox is that the avalanche-like growth of information is accompanied by information "hunger", physiological limitations of human perception and processing of information and difficulties in extracting the necessary information from the general flow. The most urgent and acute problem in the world was the problem of creating, maintaining and effective use of "information resources". There was the formation of another independent type of public resource such as information, which saves most 
other resources of society. Further progress of society is largely associated today with the improvement of information infrastructure, the efficiency of formation, placement and use of information resources and products.

We are currently talking about the global transformation of human civilization, which is based on the manifestation of the fourth industrial revolution. Mixed reality, the Internet of Things, Big Date, robotics, neural networks, biotechnology are attributes of a new technological way of life.

In the same way, digital marketing enters the activities of companies, in people's lives. Opportunities for digital marketing, digital technologies allow companies not only to meet the needs of their customers, but also to attract them to their business, while the customer receives income. We highlight several trends in the work of companies in the formation of customer experience.

1. The consumer becomes an accomplice, co-creator of the business process, while receiving income or certain benefits for the consumption of goods / services, attracting new customers. Companies offer their customers a certain percentage of the order amount for the new customer. The amounts accumulated in this way can be paid in the future as payment for consumed goods / services. In this case, a new customer who came on a recommendation receives a discount. Digital technologies allow the client to remotely track the accumulated amount of bonuses in the personal account. This marketing tool in combination with information technology is actively used by service companies: dental clinics, foreign language centers.

2. Creation of cloud services opens new opportunities, stimulates creation of new businesses joint with the consumer and positively influences consumer experience in the course of interaction with the companies. Currently on the Russian market there is a cash back platform SWITIPS, which allows the buyer to receive up to $36 \%$ of his online and offline purchases. There is a client and affiliate program. The affiliate program involves the construction of a virtual consumer network by the client. The larger the virtual consumer network, the greater the amount of cash back the creator of this network. This practice has a positive effect on the seller's relationship with customers.

3. Omni channel system of marketing communications allows you to personalize offers to customers based on their interests and previous purchases. A number of researchers note that in a digital economy, the buyer becomes active, in contrast to the industrial (traditional) economy and management of shopping experience in the new environment involves the digital transformation of the business model, the formation of a new marketing management system, online competencies and skills.

According to the results of the research, even some large enterprises operating in the Ukrainian market were not ready for the rapid digital transformation of their business. This leads to reduced profits, competitiveness. On the other hand, the results of the study allowed the authors to formulate some paradoxes of digital transformation:

Paradox 1 . The presence of a large customer base, customer performance does not allow you to develop the right marketing strategy, if we talk about the formation of consumer loyalty to the company. Practice speaks of the nonlinear relationship of consumer opinion and behavior [1].

Paradox 2. The use of digital marketing tools can significantly accelerate the path of the consumer from a potential to a loyal customer, the customer as a business partner of the company. But the joy of the consumer is significantly influenced by his emotional and behavioral experience of direct interaction with the company's staff. Therefore, a combination of online and offline formats is needed in working with customers, potential consumers [2]. 
Paradox 3. Advertising not only promotes the product, but also harms it. In general, society's attitude to advertising is sharply negative. The results of our research show that as soon as there is an advertising break in a popular TV show, the water consumption of the population increases sharply: someone puts a kettle, someone goes to the toilet. In any apartment building in front of mailboxes every day grow piles of discarded advertising garbage. If you stand and look, then almost everything is thrown away without reading.

Paradox 4. Advertising tends to decorate the advertised item. And the better it is done, the more effective it is considered. However, the more effective the advertising, the more frustrated the consumer will be and the more likely it is that even a very high quality product will be underestimated.

Paradox 5. Anti-advertising can become advertising. That is, advertising programmed for a negative effect can achieve the opposite, positive effect. For example, cigarette manufacturers were required to write on cigarette packs: smoking is harmful. Until recently, this warning was printed in small letters. And, apparently, such anti-advertising did not bring significant benefits, because recently manufacturers were obliged to write about the harm of smoking in very large letters in black on a white background "smoking kills" so the inscription takes half a pack, clearly degrading the packaging design. This anti-advertising, as explained, is aimed primarily at young people. However, there is a clear underestimation of youth psychology, often based on the denial of generally accepted behavioral norms. Therefore, groups such as hippies, punks, etc. in the youth environment from time to time gain very high popularity. To show how cool I am, many very young people go for a lot, and an inscription the size of a half-pack will not stop, but on the contrary (from the point of view of this young man) will emphasize its steepness. Therefore, the success of anti-advertising campaigns with an increase in the size of warning signs raises serious concerns.

Paradox 6. Digital marketing makes our daily lives easier and more convenient, but there is a paradox. Its essence is that despite the fact that whether digital services and technologies meet human needs, most consumers in the new reality do not feel comfortable. To understand the impact of the digital economy on society, Dents Aegis Network is conducting a global Digital Society Index survey in 24 countries, including Ukraine. According to the Digital Society Index 2019, more than 55\% of Ukrainians believe that their digital future has come too quickly. Our consumers are worried about personal data leaks, fake news, the reverse side of automation and other consequences of the spread of digital technology. Only $27 \%$ of people in our country believe that companies that store their personal data protect their privacy (against $45 \%$ in the world). Seven out of ten people say they will stop using the company's services if they find out that their data has been used unethically.

Paradox 7. Confrontation between online and offline business. The impact of internet marketing on online and offline businesses is ambiguous. Although online business has taken a significant market share in recent years, we do not believe it will completely replace offline business. Likewise, we do not believe that "new wave" online marketing will eventually replace "traditional" offline marketing. In fact, we believe that they need to coexist in parallel to provide a better customer experience. A survey by Google shows that $90 \%$ of our interactions with the media are now broadcast on the screen: smartphone, tablet, laptop and TV. Screens are becoming so important in life that we spend more than four hours of our free time every day in order to use multiple screens sequentially and simultaneously. And around all these interactions with the screen, the Internet acts as the basis. Global internet traffic grew fortyfold from 2000 to 2020, bringing together five out of ten people in the world. Cisco predicts another tenfold jump in global internet traffic by 2025 , powered by more than eleven billion connected mobile devices. On such a large scale, connectivity is changing customer behavior. When buying something in a store, most shoppers will compare prices of the item and look at reviews for it. 
A Google study shows that eight out of ten smartphone owners in the United States use an instore internet search engine. Even when watching TV ads, more than half of the TV audience of consumers in Europe uses an internet search engine on a mobile device. This trend is reaching buyers all over the world.

Various factors affect the speed of digital transformation of society: the state of the economy, the development of information and communication technologies in the country, computer literacy, the level of trust in providing their personal data. The last two indicators are especially important in the digital economy. Consumer trust, their digital involvement is also the object of digital marketing.

At present, issues related to the security of personal data on the Internet are acute. In the context of digital marketing in [3, p. 78] the concept of "digital client", the classification of the digital client is introduced. The main criterion for classification is the degree of use of digital technologies in everyday and professional life, as well as the level of readiness to provide personal data. An appropriate customer experience management system is provided for each type of digital client. Despite the many positive aspects of digital marketing associated with a high degree of personalization of the relationship between the company and its customer, digital marketing is associated with risks.

Conclusions from this research and prospects for further developments in this area. It is proved that the purpose of digital marketing is not only to promote the company on the Internet, informing about its product / service, attracting leads, retaining existing customers through digital technologies: SEO, SMO, Big Date, social networks, mobile applications, emailing. The key in the application of digital marketing is business scaling, creating virtual consumer networks, transforming the customer into a business partner. Digital technologies allow to realize these purposes in full. If before we talked about customer relationship management, now the relationship is managed by the client, which involves the individualization of companies, strengthening emotional ties with the consumer, the need to take into account the interests of each of the participants in the "consumer company".

Digital technology does not change everything around. Many consumers do not feel that digital marketing technologies meet their needs, whether they are goods or services, prosperity or new skills in a changing market. Moreover, society as a whole is largely unprepared for the digital future.

Thanks to the digital breakthrough and digital marketing, the business world has changed beyond recognition. Now consumers make their purchases without leaving home (36\% of Ukrainians, according to the international company, the world's fifth largest communications holding Dents Aegis Network) or even without leaving social networks (13\%). You can find the best prices online (42\%), manage finances (40\%), learn innovative teaching methods (12\%), make acquaintances $(10 \%)$ and more.

Thus, at this stage, digital marketing is the most popular and promising area. But currently not all marketers professionally own digital marketing tools, which is why the positive effect of using these tools is not always achieved in full. Accordingly, companies should determine which digital marketing tools are suitable for interacting with potential customers and promoting the product, and on this basis to develop and implement a marketing strategy to achieve competitive advantage and maximize revenue.

The widespread use of digital products raises concerns about their transparency and impact on health, emotional well-being and quality of life. Therefore, consumers are increasingly thinking about finding a digital marketing balance, express concern about the digital future of the markets that interest them. 
1. Lange de Bart, Stefano P., Larrik R. Lineynoye myshleniye v nelineynom mire [Linear thinking in a nonlinear world] // Harvard Business Rewiv. 2018. S. 2-13. (in Russian)

2. Arenkov I.A., Arakelova I.V, Kachalov D.L. Ot traditsionnoy loyal'nosti k upravleniyu potrebitel'skim opytom i tsifrovym modelyam [From traditional loyalty to customer experience management and digital models] // RISK. 2018. №4. S. 187-197. (in Russian)

3. Kravchenko V.O., Kryukova A.A. Ponyatiye tsifrovogo kliyenta v rossiyskom biznese [The concept of a digital client in Russian business] // Problemy ekonomiki i menedzhmenta. 2017. №1 (65). URL: https://cyberleninka.ru/article/n/ ponyatie-tsifrovogo-klienta-v-rossiyskom-biznese (in Russian)

4. Kotler F., Katardzhaia H., Setiavan Y. (2019) Marketynh 4.0. Vid tradytsiinoho do tsyfrovoho [Marketing 4.0. From traditional to digital]. Kyiv: Vydavnycha hrupa KM-BUKS, 224 p.

5. Oklander M.A. (ed.) (2017) Tsyfrovyi marketynh-model marketynhu XXI storichchia [Digital Marketing - The Marketing Model of the 21st Century]. Odesa: Astroprynt.

6. Oklander, M., Oklander, T., Yashkina, O., Pedko, I., Chaikovska, M. (2018) Analysis of technological innovations in digital marketing. Eastern-European Journal of Enterprise Technologies, no. 5/3 (95), pp. 80-91.

7. Oklander, M.A., Oklander, T.O., Yashkina, O.I. (2018) Tendentsii marketynhovykh doslidzhen: onlain paneli ta onlain spilnoty [Marketing research trends: online panels and online communities]. Marketynh i menedzhment innovatsii [Marketing and innovation management], no. 1, pp. 118-119.

8. Sokol K.M. (2014) Formuvannya marketynhovoyi stratehiyi vykhodu IT-kompaniyi na svitovyy rynok informatsiynykh tekhnolohiy [Smolovik RF Fundamentals of high technology marketing]. Foreign trade: economics, finance, law], no. 5-6, pp.76-77.

9. Compliance program of an industrial enterprise. Tutorial. (2019) Kharkov-Miskolc: NTU "KhPI", $689 \mathrm{p}$.

10. Goncharova N.P., Yakovlev A.I. (1998) Marketynh ynnovatsyonnoho protsessa [Marketing of the innovation process]. K.: VIRA-R, $267 \mathrm{p}$.

11. Internet- trendy 2019 roku. Statystyka ta fakty v SShA ta v usomu sviti [Internet trends in 2019. Statistics and Facts in the United States and Worldwide]. www.uk.vpnmentor.com Retrieved from : https://uk.vpnmentor.com/blog/ (in Ukrainian)

12. Oklander, M.A., Oklander, T.O., Pedko, I. A., \& Yashkina, O.I. (2017). Marketynhovi doslidzhennia innovatsii ta pidpryiemnytski ryzyky [Marketing Research Innovations and Business Risks]. Oklander, M.A. (Ed). Odesa: Astroprint [in Ukrainian].

13. Oklander, T.O. (2011). Innovatsiini metody vplyvu na spozhyvachiv: aromamarketynh [Innovative methods of influencing consumers: aroma marketing]. Marketynh i menedzhment innovatsii-Marketing and management of innovations, 3, 97-101 [in Ukrainian].

14. Kotler F., Katardzhaia H., Setiavan Y. (2019) Marketynh 4.0. Vid tradytsiinoho do tsyfrovoho [Marketing 4.0. From traditional to digital]. Kyiv: Vydavnycha hrupa KM-BUKS, 224 p.

П.Г. Перерва, д-р екон.наук, професор, завідувач кафедри менеджменту інновачійного підприсмництва та міжснародних економічних відносин, Національний технічний університет «Харківський політехнічний інститут» (Харків, Україна).

В.М. Кобєлєв, канд. екон.наук, доцент, заступник директора навчально-наукового інституту економіки, менеджменту та міжнародного бізнесу, Національний технічний університет «Харківський політехнічний інститут» (Харків, Украӥна).

I.B. Долина, кандидат економічних наук, дочент, професор кафедри менеджменту інновачійного підприємництва та міжнародних економічних відносин, Начіональний технічний університет «Харківський політехнічний інститут» (Харків, Україна).

\section{Цифровий маркетинг: можсливості і парадокси комунікацій}

Поява цифрових мереж в людському суспільстві, в маркетинговій діяльності $\epsilon$ життєвою потребою суспільства обмінюватися інформацією. Можливості цифрового маркетингу, ичифрових технологій дозволяють компаніям не тільки задовольняти потреби свого клієнта, а й залучати його в свій бізнес, при цьому клієнт отримує дохід. В статті виділено основні тренди в роботі підприємств при формуванні клієнтського досвіду: споживач стає 
співучасником, співтворием бізнес-прочесу; створення хмарних сервісів відкриває нові можливості; система маркетингових комунікацій дозволяе персоніфікувати пропозииіі клієнтам з урахуванням їх інтересів та попередніх покупок. Доведено, що иифровим трансформачіям в маркетингу притаманні і деякі парадоксальні прояви. Серед них: велика база споживачів не є основою для вірної стратегії; иифровий маркетинг не скорочує час на покупку; реклама не тільки просуває товар, але $і$ шкодить йому та схильна прикрашати предмет реклами; антиреклама може стати рекламою.

Ключові слова: цифрові трансформації, маркетинг, реклама, парадокс, тренд, споживачі, стратегія, промислові підприємства

Received to the editor 11 June 2020. 